\title{
Liver X Receptor Activation with an Intranasal Polymer Therapeutic Prevents Cognitive Decline without Altering Lipid Levels
}

\author{
María Eugenia Navas Guimaraes, ${ }^{\nabla}$ Roi Lopez-Blanco, ${ }^{\nabla}$ Juan Correa, Marcos Fernandez-Villamarin, \\ María Beatriz Bistué, Pamela Martino-Adami, Laura Morelli, Vijay Kumar, Michael F. Wempe, \\ A. C. Cuello, Eduardo Fernandez-Megia,* and Martin A. Bruno*
}

Cite This: ACS Nano 2021, 15, 4678-4687

Read Online

ACCESS | Lلll Metrics \& More | 回 Article Recommendations

ABSTRACT: The progressive accumulation of amyloid-beta $(\mathrm{A} \boldsymbol{\beta})$ in specific areas of the brain is a common prelude to lateonset of Alzheimer's disease (AD). Although activation of liver $\mathrm{X}$ receptors (LXR) with agonists decreases $\mathrm{A} \beta$ levels and ameliorates contextual memory deficit, concomitant hypercholesterolemia/hypertriglyceridemia limits their clinical application. DMHCA ( $N, N$-dimethyl-3 $\beta$-hydroxycholenamide) is an LXR partial agonist that, despite inducing the expression of apolipoprotein $E$ (main responsible of $A \boldsymbol{\beta}$ drainage from the

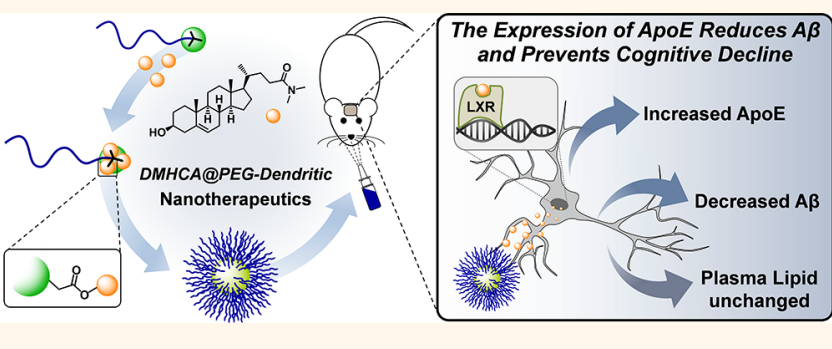
brain) without increasing cholesterol/triglyceride levels, shows nil activity in vivo because of a low solubility and inability to cross the blood brain barrier. Herein, we describe a polymer therapeutic for the delivery of DMHCA. The covalent incorporation of DMHCA into a PEG-dendritic scaffold via carboxylate esters produces an amphiphilic copolymer that efficiently self-assembles into nanometric micelles that exert a biological effect in primary cultures of the central nervous system (CNS) and experimental animals using the intranasal route. After CNS biodistribution and effective doses of DMHCA micelles were determined in nontransgenic mice, a transgenic AD-like mouse model of cerebral amyloidosis was treated with the micelles for 21 days. The benefits of the treatment included prevention of memory deterioration and a significant reduction of hippocampal $\mathbf{A} \boldsymbol{\beta}$ oligomers without affecting plasma lipid levels. These results represent a proof of principle for further clinical developments of DMHCA delivery systems.

KEYWORDS: Alzheimer's disease, amyloid-beta, liver X receptor, DMHCA, dendrimer, polymeric micelle, drug delivery

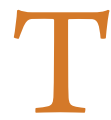
he progressive accumulation of amyloid-beta $(\mathrm{A} \beta)$ in specific areas of the brain is a common prelude to lateonset of Alzheimer's disease $(\mathrm{AD}) .^{1}$ The amyloidcascade hypothesis has been for more than 25 years the central dogma for the development of $\mathrm{AD} .^{2,3}$ This hypothesis states than imbalance between the production and clearance of $\mathrm{A} \beta$ in the brain of affected individuals is responsible for neurodegeneration and dementia. Monomeric A $\beta$ progressively aggregates into $\mathrm{A} \beta$ oligomers and finally into amyloid fibrils, found in $\mathrm{AD}$ plaques previously considered to be the cause of cognitive deficits. Since the amounts of $A \beta$ fibrillar plaques do not correlate with cognitive decline, ${ }^{4,5}$ researchers have focused on the study of both soluble and membrane-associated $\mathrm{A} \beta$ oligomers to identify the $\mathrm{A} \beta$ form responsible for neurotoxicity. In this regard, strong evidence suggests that instead of monomer or $\mathrm{A} \beta$ fibrils, diffusible $\mathrm{A} \beta$ oligomers are largely suspected to be responsible for development and progression of cognitive deterioration characteristic of $\mathrm{AD}$, causing direct injury to neurons, enhancing neuroinflammation, astrocytosis, gliosis, and eventually neuronal loss. ${ }^{2,6,7}$ As a result, the age-related impairment of $\mathrm{A} \beta$ homeostatic mechanisms has been postulated as a critical determinant of disease risk with even modest reductions in clearance of soluble $\mathrm{A} \beta$ resulting in elevated levels of $\mathrm{A} \beta$ oligomers and ultimately their progressive and chronic deposition within the brain. This process occurs while individuals are still cognitively normal. Thus, early intervention aimed to eliminating toxic $\mathrm{A} \beta$ oligomers in the brain offer a promising preventive therapeutic strategy not only to halt the development and progression of

Received: November 2, 2020

Accepted: March 2, 2021

Published: March 5, 2021 

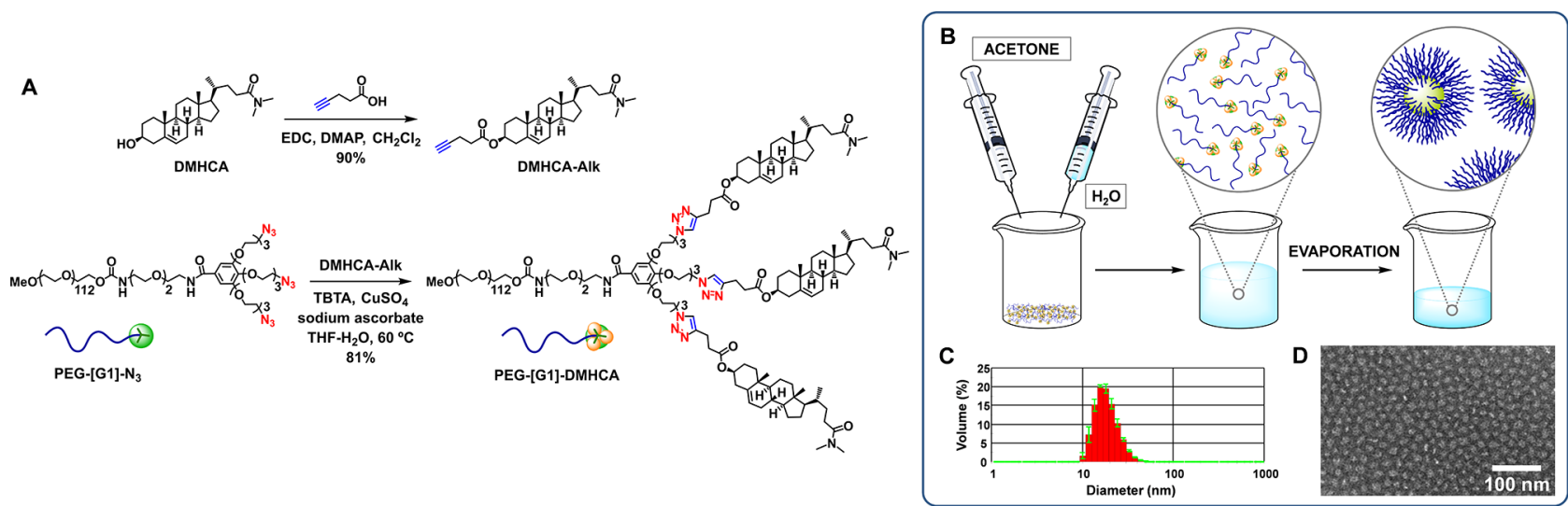

Figure 1. Synthesis of PEG-[G1]-DMHCA (A). Preparation of micelles (B). DLS histogram (C) and TEM image (D) of micelles.

$\mathrm{AD}$ but also as a promising target for causal treatment of the disease.

The main contribution to $\mathrm{A} \beta$ drainage from the brain comes from apolipoprotein $\mathrm{E}$ (ApoE), ${ }^{8,9}$ the strongest genetic risk factor of $\mathrm{AD},{ }^{10}$ which modulates $\mathrm{A} \beta$ removal to the systemic circulation by its transport across the blood brain barrier (BBB). ${ }^{11,12}$ The interaction between ApoE and $\mathrm{A} \beta$ is conditioned by the correct lipidation of ApoE, which is induced by the ATP-binding cassette transporter A1 (ABCA1). ${ }^{13,14}$ When amyloid precursor protein (APP) $\mathrm{Tg}$ mice are crossed onto an $\mathrm{ABCA1}^{-/-}$background, decreased ApoE lipidation and increased amyloid deposition are observed, ${ }^{13,15,16}$ whereas increasing ABCA1 favors ApoE lipidation and reduces amyloid deposition. ${ }^{14}$ Both ApoE and ABCA1 are modulated by cerebral expression of liver $\mathrm{X}$ receptors (LXRs) and mainly produced in the central nervous system (CNS) by astrocytes. ${ }^{17}$

Several studies have explored the potential utility of LXRs agonists in $\mathrm{AD}$ therapy. ${ }^{13,14,17,18}$ In vivo studies using $\mathrm{AD}$-like transgenic mouse models have revealed that LXRs agonists provoke an upregulation of $\mathrm{ApoE}$ and $\mathrm{ABCA1}$ expression, a marked reduction in $\mathrm{A} \beta$ levels, enhanced brain cholesterol turnover, and reversed contextual memory deficits. ${ }^{19-21}$ However, a major concern with LXRs agonists is that they not only drive up transcription of ApoE and ABCA1 but also upregulate genes associated with fatty acid synthesis. As a result, the therapeutic application of LXRs agonists has been restricted due to undesirable side effects, promoting lipogenesis and triglyceride accretion through the activation of sterol-response element binding protein 1c (SREBP-1c) expression. $^{22}$

DMHCA ( $N, N$-dimethyl-3 $\beta$-hydroxycholenamide, Figure 1$)$ is a gene-selective LXR modulator that mediates potent transcriptional activation of $\mathrm{ABCA} 1$ and $\mathrm{ApoE}$ gene expression, while minimally affecting SREBP-1c. ${ }^{22,23}$ Thus, it represents an excellent therapeutic candidate for $\mathrm{AD}$, circumventing the side effects of alternative LXRs agonists. Still, DMHCA's very low solubility and inability to cross the BBB limits its application in vivo. ${ }^{24}$ To overcome these shortcomings and achieve enough delivery to target areas of the brain, herein we describe the covalent incorporation of DMHCA into a micellar polymer therapeutic, exploiting its unique hydroxyl group as chemical handle. Functionalization of a PEG-dendritic scaffold ${ }^{25}$ [PEG is poly(ethylene glycol), a linear, hydrophilic polymer, characterized by low toxicity and immunogenicity and widely used for biomedical applica- tions $]^{26}$ with DMHCA has afforded an amphiphilic copolymer with precise stoichiometry that efficiently self-assembles into nanometric micelles (Figure 1) for intranasal administration.

\section{RESULTS AND DISCUSSION}

Figure 1 shows PEG-[G1]-DMHCA, a conjugate incorporating a PEG $_{5 \mathrm{k}}$ chain, a GATG (gallic acid-triethylene glycol) ${ }^{27-29}$ dendritic block of first generation, and three pendant DMHCA molecules connected via carboxylate esters. These linkages were selected because of their known biodegradability in vivo by $\mathrm{pH}$ and the action of esterases and thus frequent use in the design of prodrugs. ${ }^{30-32}$ In addition, esters show a good compromise between biodegradability and synthetic manipulation. GATG dendrimers have been developed in our laboratory as a platform for biomedical applications. ${ }^{27-29}$ They are composed of a repeating unit incorporating a gallic acid core and hydrophilic triethylene glycol arms carrying terminal azides. ${ }^{33}$

The synthetic strategy toward PEG-[G1]-DMHCA has relied on an initial esterification of DMHCA with 4-pentynoic acid to afford DMHCA-Alk (EDC, DMAP, 90\%), an alkynated derivative that was then connected via $\mathrm{Cu}(\mathrm{I})$-catalyzed azidealkyne cycloaddition (CuAAC) ${ }^{34}$ to PEG-[G1]-N $\mathrm{N}_{3}$, a dendritic copolymer carrying three terminal azides, available in gram quantities in just one step $^{35}$ (Figure 1). A proper selection of the reaction conditions and the presence of catalytic tris(benzyltriazolylmethyl) amine (TBTA) were determining factors to efficiently lead $\mathrm{CuAAC}$ to completion $\left[\mathrm{CuSO}_{4}\right.$, ascorbate, TBTA, THF $/ \mathrm{H}_{2} \mathrm{O}(4: 1), 60{ }^{\circ} \mathrm{C}$; see Table S1). PEG-[G1]-DMHCA was obtained in very good yield (81\%) and chemically characterized with convincing evidence by ${ }^{1} \mathrm{H}$ NMR (disappearance of the methylene protons adjacent to the azide at $3.40 \mathrm{ppm}$, appearance of new triazol protons at 7.51 ppm), ${ }^{13} \mathrm{C}$ NMR (new triazol at 122.2 and $127.9 \mathrm{ppm}$ ), IR spectroscopy (loss of the intense azide band at $2100 \mathrm{~cm}^{-1}$ ), and MALDI-TOF MS (a series of 44 Da spaced peaks with $M_{\mathrm{p}}$ and $M_{\mathrm{w}}$ in agreement with expected values) as described in Supporting Information (SI). In addition, characteristic new signals in the ${ }^{1} \mathrm{H}$ NMR [5.35 (alkene) and 3.00-2.93 ppm (N,N-dimethylamide) $]$ and ${ }^{13} \mathrm{C}$ NMR spectra $[173.6 \mathrm{ppm}$ (amide) and $139.5 \mathrm{ppm}$ (alkene)] confirmed the incorporation of DMHCA.

Micellar assembles of PEG-[G1]-DMHCA were obtained by an evaporation method in acetone $/ \mathrm{H}_{2} \mathrm{O}$ (1:1). Dynamic light scattering (DLS) measurements confirmed a mean diameter of about $22 \pm 1 \mathrm{~nm}$ in agreement with transmission electron 


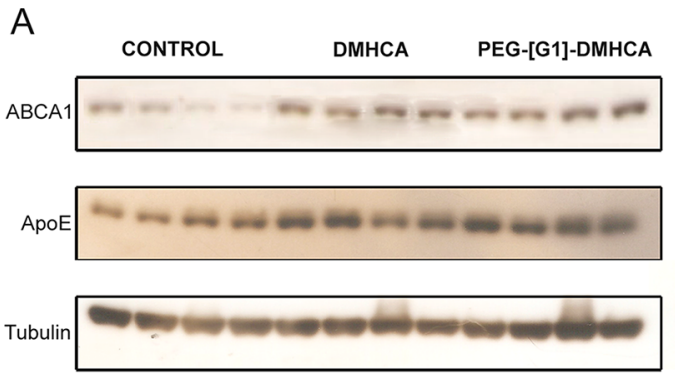

\section{B}
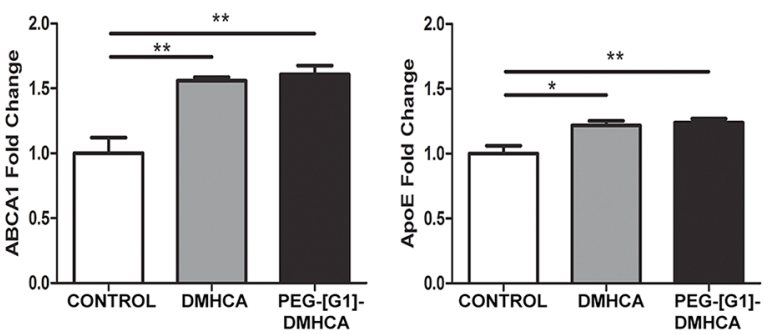

C

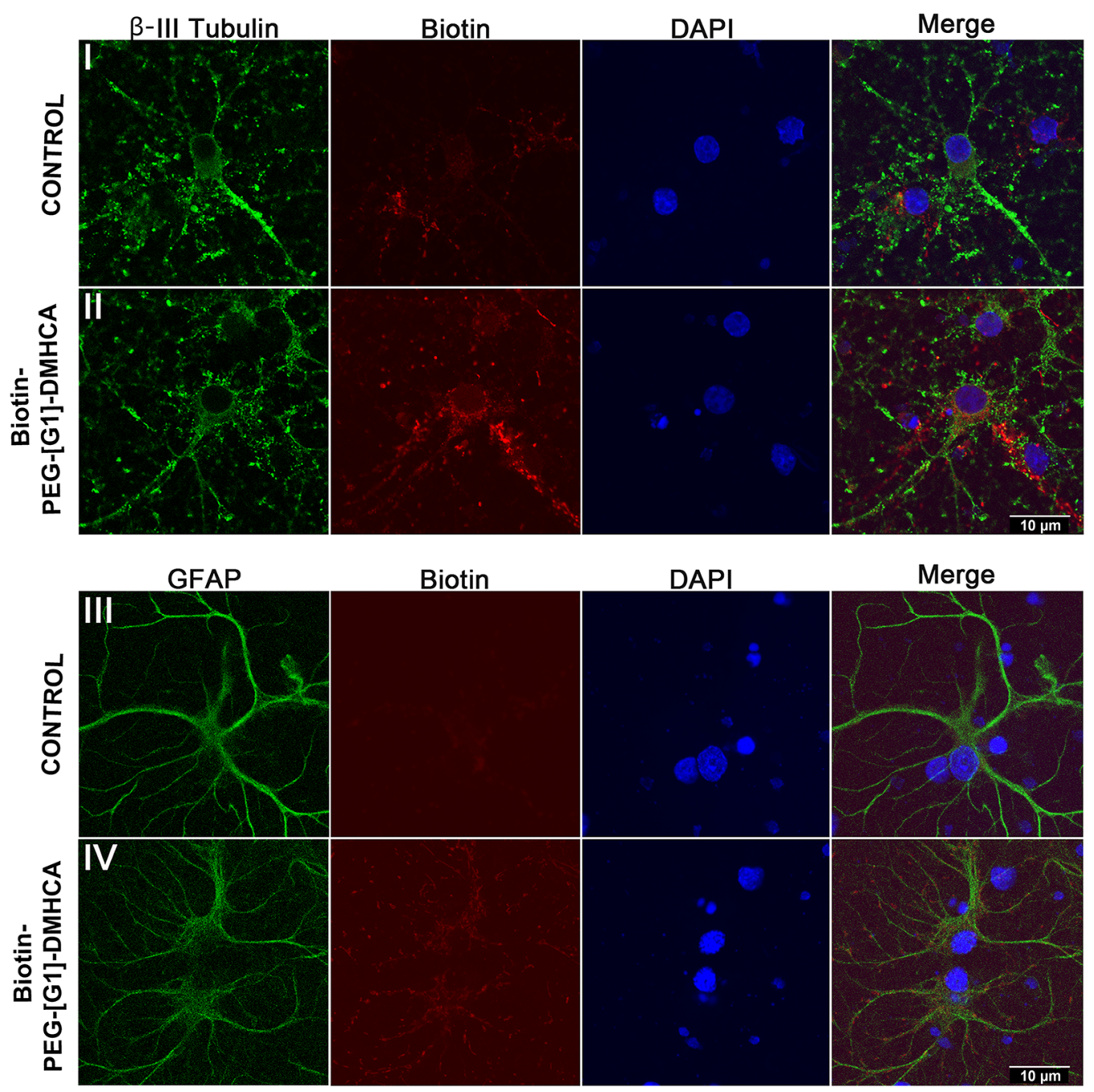

Figure 2. Biological effect of free DMHCA versus PEG-[G1]-DMHCA micelles versus PEG-[G1]-CO ${ }_{2} \mathrm{H}$ (control) over ABCA1 and ApoE levels tested on cerebral cortical cocultures treated for 24 h (A,B). Statics analysis were performed using GraphPad Prism 6. All probability values were two-tailed; a level of $5 \%$ was considered significant. Data are reported as the mean \pm SEM. Confocal microscopy (C) of displaying neuronal (panel II; $\beta$ III-tubulin, green) and astrocytes (panel IV; GFAP, green) binding Biotin-PEG-[G1]-DMHCA (red) compared with controls (panels I and III, respectively). Nuclei stained in blue (DAPI). Scale bar, $10 \mu \mathrm{m}$.

microscopy (TEM) images (Figures 1 and S2). These micelles containing a high $20 \%$ DMHCA drug loading were stable in solution for at least 1 week without variation in size or ester hydrolysis being observed (Figure S6). They could be freezedried and successfully resuspended in PBS (Figure S3), both relevant properties for storage and handling. Finally, to proceed with an in vitro/in vivo evaluation, a biotinylated version of the micelles was obtained from Biotin-PEG-[G1]DMHCA, a copolymer carrying biotin at the distal end of the PEG block prepared following a similar strategy from BocHNPEG- $[\mathrm{G} 1]-\mathrm{N}_{3}$ (a copolymer analogous to PEG-[G1]- $\mathrm{N}_{3}$ that incorporates a terminal protected amino group $)^{36}$ (Scheme S1 and Figure S4).

To determine the therapeutic efficacy of PEG-[G1]DMHCA, we compared the effect of DMHCA versus PEG[G1]-DMHCA micelles on the ABCA1 and ApoE cell expression (PEG-[G1]- $\mathrm{CO}_{2} \mathrm{H}$, the block copolymer resulting after hydrolysis of DMCHA was used as control). After 14 days in vitro, rat cortical neuronal and glial cocultured cells (800000 cells per well) were treated for $24 \mathrm{~h}$ with $10 \mu \mathrm{M}$ free or micellar DMHCA. Levels of ABCA1 and ApoE were resolved by Western blots (Figure 2A). As depicted in Figure 2B, there 


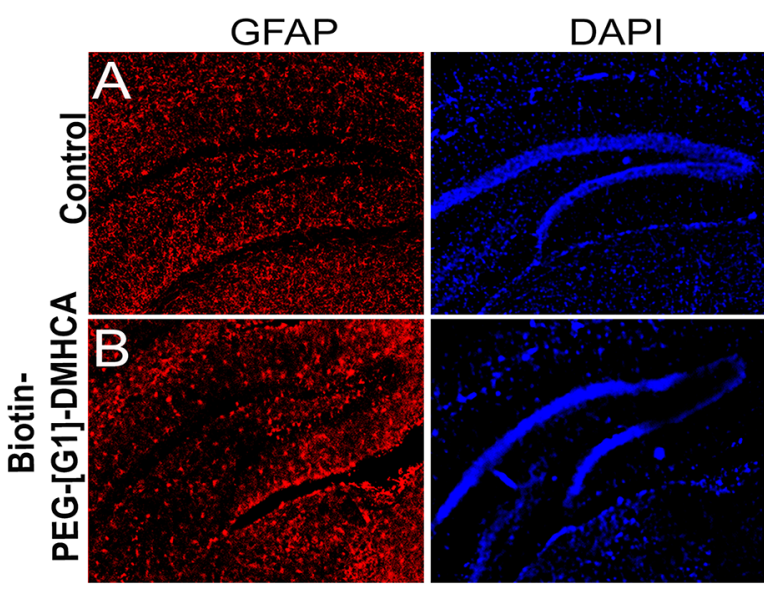

C

DMHCA experimental dose C Ctl $0.3 \mathrm{mg} 1.5 \mathrm{mg} 3 \mathrm{mg} 15 \mathrm{mg}$ ApoE $\rightleftharpoons \cdots \infty \omega \infty \begin{gathered}\text { Olfator } \\ \text { bulb }\end{gathered}$

Olfatory bulb ApoE levels

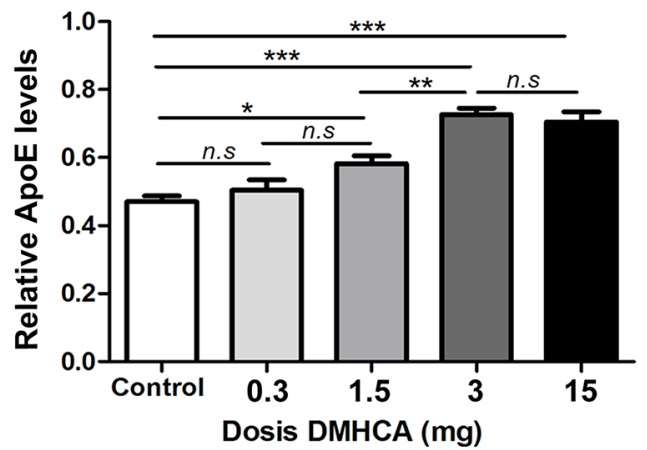

D Ctl $4 \mathrm{~h} 12 \mathrm{~h} 24 \mathrm{~h} 48 \mathrm{~h} 72 \mathrm{~h}$ ApoE $=-\ldots=-\ldots$ Hipp.
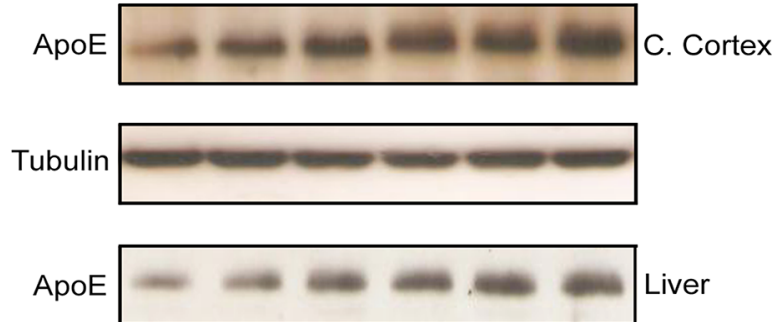

GAPDH

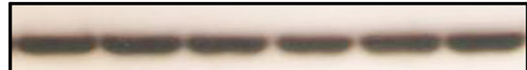

Biotin
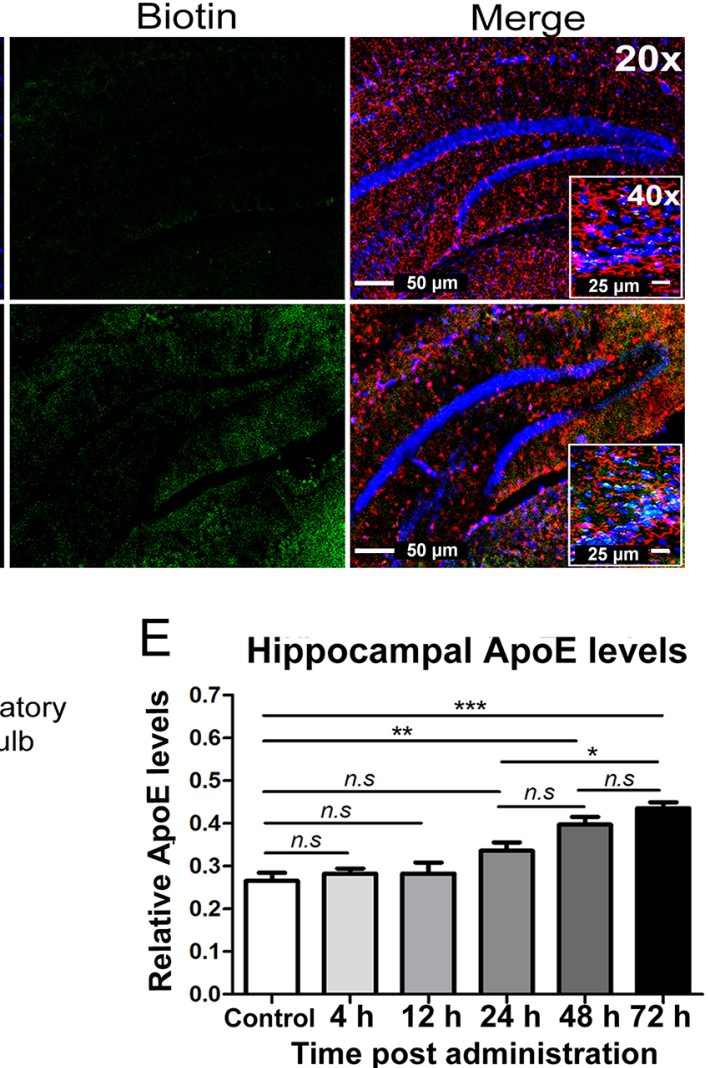

Cerebral Cortex ApoE levels
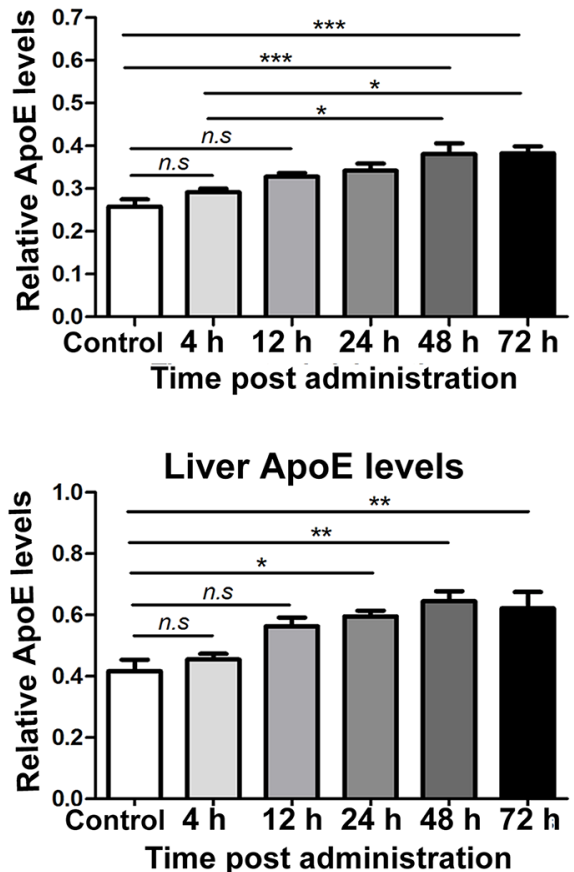

Figure 3. Biotin-PEG-[G1]-DMHCA intranasally administered reaches the hippocampus after $24 \mathrm{~h}$. In the images, the colocalization of the used markers (red for GFAP/blue for DAPI, nuclei/green for Biotin) can be observed at 20× and $40 \times$ (scale bars 50 and $25 \mu \mathrm{m}$, respectively) (A,B). Effective intranasal dose analysis in mice: olfactory bulb levels of ApoE evaluated after $24 \mathrm{~h}$ by Western Blot (C). Relative levels of ApoE in homogenates of hippocampus, cerebral cortex, and liver; normalizing with values of $\beta$ III-tubulin for hippocampus and cerebral cortex, and GAPDH for liver (D,E). Statics analysis was performed using Graph-Pad Prism 6. All probability values were twotailed; a level of $5 \%$ was considered significant. Data are reported as the mean \pm SEM.

were statistically significant increases in both target proteins in free DMHCA treated cells versus control $\left(t\right.$ test $p \leq 0.01^{* *}$ and $p \leq 0.05^{*}$, respectively) and DMHCA micelles treated cells versus control ( $t$ test $p \leq 0.01 * *$ for both markers). The 
A Novel Object Recognition Test

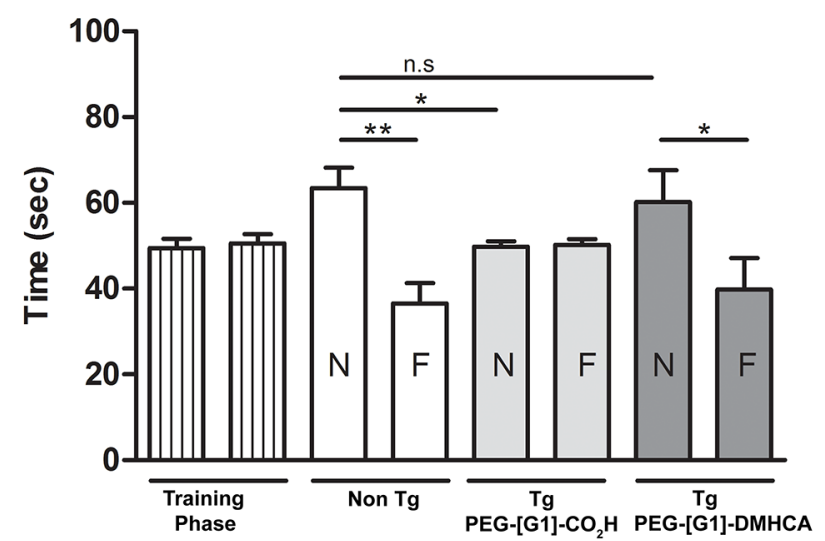

B

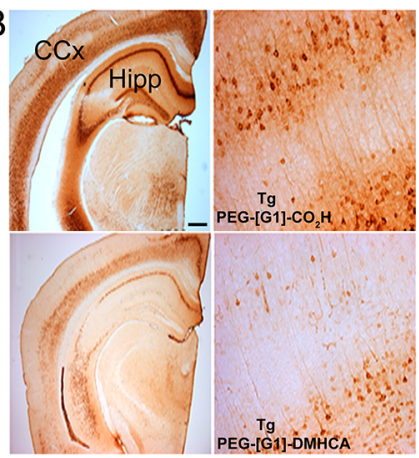

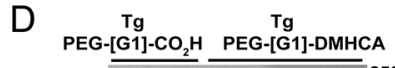

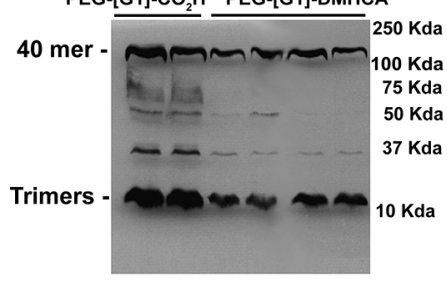

Tubulin - enemenese

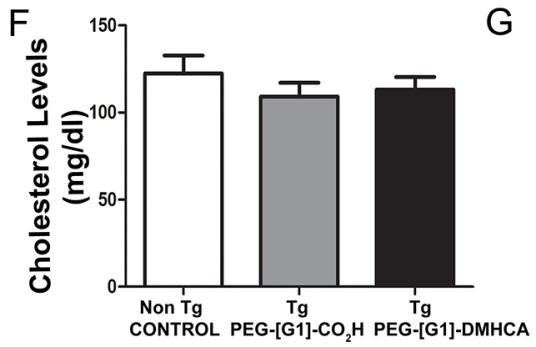

C

E
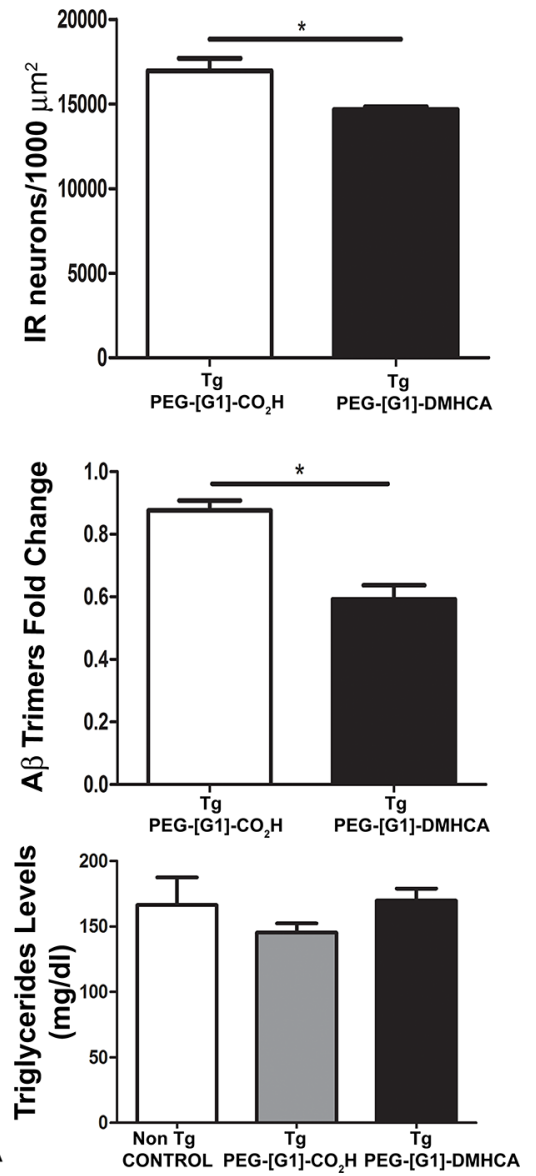

Figure 4. (A) Novel object recognition test: memory retention was tested $24 \mathrm{~h}$ after training. Data are mean \pm SEM exploratory preferences during training (left columns) or test (white and gray columns; $\mathrm{F}$, familiar; $\mathrm{N}$, novel) trials $(n=8$ per group). (B) Immunoreactive $\mathrm{A} \beta$ burden in the cerebral cortex $\left(\mathrm{CCx}\right.$ ) and hippocampus (Hipp) of PEG-[G1]-CO $\mathrm{C}_{2} \mathrm{H}$ versus PEG-[G1]-DMHCA treated mice. (C) Positive immunoreactive neurons were quantified using the Image Pro Plus software. (D) Hippocampal homogenates were resolved by Western blots using the $6 \mathrm{E} 10$ antibody; a particular reduction of the $12 \mathrm{kDa}$ band, referred as $\mathrm{A} \beta$ trimers $(p \leq 0.05, *$, independent $t$ test) was observed (E). Lipid plasma profile shows not statistically significant differences (independent $t$ test) in the levels of cholesterol (F) and triglycerides (G) among groups. Statics analysis were performed using Graph-Pad Prism 6. All probability values were two-tailed; a level of 5\% was considered significant. Data are reported as the mean \pm SEM.

most striking finding is that both DMHCA and PEG-[G1]DMHCA micelles upregulated target protein expression with respect to control with no statistical differences between them, confirming that PEG-[G1]-DMHCA micelles exert in vitro selective biological effects on ABCA1 and ApoE through LXRs activation.
Then, the target specificity of PEG-[G1]-DMHCA was evaluated by confocal imaging using the biotinylated version of the micelles. Neurons and astrocytes were incubated with Biotin-PEG-[G1]-DMHCA micelles (10 $\mu \mathrm{M}$ DMHCA) for 2 h. The distribution of Biotin-PEG-[G1]-DMHCA was examined, staining biotin with streptavidin-Alexa Fluor 594 
(red) and nuclei with DAPI (blue). Neurons were marked with an anti- $\beta$ III-tubulin and a secondary antibody labeled with Alexa Fluor 488 (green). Biotin-PEG-[G1]-DMHCA displayed a strong signal and colocalized with neurons compared with control cells (Figure 2C, panels I and II). Similarly, astrocytes labeled with anti-GFAP (glial fibrillary acidic protein) and a secondary antibody-Alexa Fluor 488 (green) overlapped with Biotin-PEG-[G1]-DMHCA (red) (Figure 2C, panel III and control in panel IV). Overall, confocal imaging for primary cell culture displayed fluorescence intensity for both, neurons and astrocytes.

Having demonstrated the colocalization of PEG-[G1]DMHCA with cells of the CNS in vitro, the in vivo administration of micelles was evaluated in mice. Drug delivery to the brain for the treatment of a wide variety of diseases has been traditionally hampered by the BBB. In recent years, the intranasal administration has come to light as an effective noseto-brain passage that circumvents the BBB. The olfactory epithelium provides a direct pathway for the noninvasive, rapid, and comfortable delivery of therapeutic agents and drug delivery systems, including dendrimer nanoplatforms, to the CNS. $^{37-39}$ Administration doses of $0.2,5$, and $10 \mathrm{mg}$ $\mathrm{DMHCA} / \mathrm{kg}$ body weight/day (equivalent to 1,25 , and 50 $\mathrm{mg}$ of DMHCA micelles $/ \mathrm{kg}$ body weight/day) were tested by intranasal administration. Mice received $5 \mu \mathrm{L}$ per nostril of a solution of Biotin-PEG-[G1]-DMHCA micelles and after 4, 12 , and $24 \mathrm{~h}$ of administration, cerebral cortex and hippocampus were analyzed (Figure 3 ). At $24 \mathrm{~h}$ post intranasal administration, confocal images $(20 \times)$ delivered an overlapped green signal from Biotin-PEG-[G1]-DMHCA (stained with streptavidin-Alexa Fluor 488) and an astrocytes red signal from GFAP (marked with anti-GFAP followed by a secondary antibody-Alexa Fluor 594) in treated mice versus controls both at 5 and $10 \mathrm{mg}$ of DMHCA/ $\mathrm{kg}$ body weight/day (Figure $3 A, B)$. At higher magnification $(40 X)$, in some images of the hippocampus, Biotin-PEG-[G1]-DMHCA also overlapped with DAPI (blue), indicating accumulation in the nuclei, where LXRs are expressed (Figure 3B).

In previously reported studies of DMHCA, experimental doses in mice ranged from 8 to $80 \mathrm{mg} / \mathrm{kg}$ body weight/day for systemic or oral administration, without penetration through the BBB. ${ }^{22,23,40}$ We explored a range of four different doses of DMHCA, $0.3,1.5,3$, and $15 \mathrm{mg} / \mathrm{kg}$ body weight/day, equivalent to $1.5,7.5,15$, and $75 \mathrm{mg}$ of PEG-[G1]$\mathrm{DMHCA} / \mathrm{kg}$ body weight/day. Animals were divided in five groups ( $n=4$ per group) and received a single intranasal dose with increasing concentrations of DMHCA micelles $(10 \mu \mathrm{L}$ total volume, $5 \mu \mathrm{L} /$ nostril). After $24 \mathrm{~h}$, mice were deeply anaesthetized and brains were rapidly removed. As depicted in Figure 3C, olfactory bulb levels of ApoE resolved by Western blots revealed that mice receiving $3 \mathrm{mg}$ of DMHCA displayed increased relative ApoE levels compared to controls ( $p \leq$ $0.001, * * *)$ and the $0.3 \mathrm{mg}(p \leq 0.001, * * *)$ and $1.5 \mathrm{mg}(p \leq$ $0.01, * *)$ groups. However, no significant differences were observed between the 3 and $15 \mathrm{mg}$ groups. Altogether, we concluded that $3 \mathrm{mg}$ of DMHCA/ $\mathrm{kg}$ body weight/day displayed an effective dose-response, triggering upregulation of ApoE levels. As expected, the intranasal treatment of free DMHCA at the same concentrations did not affect the levels of ApoE.

To check the effectiveness of the selected pharmacological dose of DMHCA micelles (3 mg DMHCA/ $\mathrm{kg}$ body weight/ day) at different times post intranasal administration, experimental mice were divided into six groups $(n=5$ per group), as follows: group A (control), saline; group B, one dose administered at time 0 and sacrificed $4 \mathrm{~h}$ later; group $\mathrm{C}$, one dose at time 0 and sacrificed after $12 \mathrm{~h}$, group $\mathrm{D}$, one dose at time 0 and sacrificed after $24 \mathrm{~h}$; group E, two doses at time 0 and $24 \mathrm{~h}$, sacrificed at $48 \mathrm{~h}$ post first administration; and group $\mathrm{F}$, three doses at time 0,24 , and $48 \mathrm{~h}$, sacrificed at $72 \mathrm{~h}$ post first administration. As shown in Figure 3D, relative ApoE levels were determined by Western blots in hippocampus, cerebral cortex, and liver. Quantification in Figure 3E shows a significant increase in ApoE levels at $48 \mathrm{~h}$ post initial administration in hippocampus and cerebral cortex. An increase in ApoE levels $\left(p \leq 0.05,{ }^{*}\right)$ at $24 \mathrm{~h}$ post initiation of administration is also observed in liver likely due to the high LXRs hepatic expression.

Next, we investigated the potential in vivo pharmacological effects of PEG-[G1]-DMHCA micelles on associated memory impairment and $\mathrm{A} \beta$ burden in our well-characterized $\mathrm{AD}$-like amyloid pathology transgenic $(\mathrm{Tg})$ mice. ${ }^{41}$ Three month old mice were divided into two groups. A control group received daily $10 \mu \mathrm{L}(5 \mu \mathrm{L} /$ nostril) intranasal administration of PEG[G1] $-\mathrm{CO}_{2} \mathrm{H}$ (copolymer lacking DMHCA; $15 \mathrm{mg} / \mathrm{kg}$ body weight/day) for 21 consecutive days. The experimental group followed the same protocol and received $15 \mathrm{mg} / \mathrm{kg}$ body weight/day of DMHCA micelles (equivalent to $3 \mathrm{mg}$ DMHCA/ $\mathrm{kg}$ body weight/day). At the end of the treatment, we investigated whether chronic intranasal treatment with PEG-[G1]-DMHCA could prevent object recognition memory deficits characteristic of our $\mathrm{Tg}$ mice at this age [novel object recognition test (NOR)]. Gratifyingly, PEG-[G1]-DMHCA treated mice performed significantly better on the object recognition task than control mice $\left(p<0.05\right.$, $\left.^{*}\right)$ and similar to nontransgenic age-matched littermates (Figure 4A). Figure 4B illustrates the immunoreactive $\mathrm{A} \beta$ burden in the right cerebral cortex and hippocampus of PEG-[G1]- $\mathrm{CO}_{2} \mathrm{H}$ versus PEG[G1]-DMHCA treated mice. The study revealed a significant reduction $(p \leq 0.05, *)$ of $\mathrm{A} \beta$ positive neurons following PEG[G1]-DMHCA treatment compared to control (Figure 4C). Left hippocampal homogenates were resolved by Western blots using the 6E10 antibody (Figure 4D). The analysis revealed several immunoreactive bands in Tg/PEG-[G1]$\mathrm{CO}_{2} \mathrm{H}$ animals between 12 and $120 \mathrm{kDa}$, mainly oligomeric forms of $\mathrm{A} \beta$ not appearing in hippocampal Tg/PEG-[G1]DMHCA homogenates. Clearly, the micellar DMHCA treatment results in the clearance of most of the hippocampal 6E10 immunoreactive bands with a particular reduction of the 12 $\mathrm{kDa}$ band, referred to as $\mathrm{A} \beta$ trimers ( $p \leq 0.05$, ; Figure $4 \mathrm{E})$. Lastly, considering that significant efforts are currently directed toward developing LXRs ligands that lack an undesired upregulation of hepatic lipogenesis, the lipid plasma profile was studied, revealing no statistically significant differences in the plasma levels of cholesterol and triglycerides among groups (Figure 4F,G).

Finally, the potential cytotoxicity of the intranasal treatment with DMHCA micelles was evaluated in mice using a caspase $3 / 7$ assay. Apoptosis is the process of programmed cell death that occurs in all living organisms. Detecting apoptosis is key to determine mechanisms of cell toxicity. In mammalian cells, apoptosis is accompanied by an increased production of caspases, enzymes responsible for the activation of signaling pathways and the proteolytic dismantling of key processes ultimately leading to cell death. To study the potential cytotoxic effects in vivo of PEG-[G1]-DMHCA micelles, we 
have investigated the specific activation of two effector caspases, caspase- 3 and 7, which are downstream of the initiator events of the apoptotic cascade (see the SI). The analysis of homogenates of the olfactory bulb, hippocampus, cerebral cortex and liver of mice treated with PEG-[G1]DMHCA micelles at different time-points (up to $72 \mathrm{~h}$ ) indicates that the treatment does not mediate in vivo cell toxicity through an apoptotic mechanism at any of the experimental doses (Figure S7). The cytotoxic effect of the long-term PEG-[G1]-DMHCA treatment was also studied in 21 days-treated transgenic mice (Figure S8). Our studies do not reveal any statistical differences in caspase $3 / 7$ activity between tissues [brain (olfactory bulb, hippocampus, and cerebral cortex), liver, lungs, and heart] of non $\mathrm{Tg}$ and $\mathrm{Tg}$ mice treated with PEG-[G1]- $\mathrm{CO}_{2} \mathrm{H}$ (control) or PEG-[G1]DMHCA micelles. Overall, our results indicate that the longterm intranasal treatment of PEG-[G1]-DMHCA micelles at the experimental dose $(3 \mathrm{mg} / \mathrm{kg}$ body weight/day) does not trigger caspase-related cell toxicity mechanisms in our mice model.

\section{CONCLUSIONS}

The age-related impairment of $\mathrm{A} \beta$ homeostatic mechanisms has been postulated as a critical determinant of disease risk in $\mathrm{AD}$ with even modest reductions in the clearance of soluble $\mathrm{A} \beta$ resulting in elevated levels of toxic oligomers, and ultimately their progressive and chronic deposition within the brain. DMHCA represents an LXR partial agonist that despite inducing the expression of ApoE (mainly responsible of $\mathrm{A} \beta$ drainage from the brain) shows nil activity in vivo because of low solubility/inability to cross the BBB. Our DMHCA polymer therapeutic approach of intranasally administered dendritic micelles at very early stages of the pathology effectively prevents cognitive deficits assessed by the NOR test and reduces $\mathrm{A} \beta$ deposition without undesirable side effects, leaving the plasma levels of cholesterol and triglycerides unaffected. We believe these studies render suitable proof of principle for further successful clinical applications of DMHCA delivery systems.

\section{EXPERIMENTAL SECTION}

Synthesis of DMHCA-Alk. DMHCA (100 mg, $0.25 \mathrm{mmol})$, DMAP (6.1 mg, $49.8 \mu \mathrm{mol})$, and EDC. $\mathrm{HCl}(62 \mathrm{mg}, 0.32 \mathrm{mmol})$ were added to a solution of 4-pentynoic acid $(29 \mathrm{mg}, 0.30 \mathrm{mmol}$ ) in $\mathrm{CH}_{2} \mathrm{Cl}_{2}(0.5 \mathrm{~mL})$ under Ar. After $20 \mathrm{~h}$ of stirring at room temperature, the solvent was evaporated and the mixture was diluted with $\mathrm{CH}_{2} \mathrm{Cl}_{2}(15 \mathrm{~mL})$ and washed with $0.5 \mathrm{M} \mathrm{HCl}(2 \times 10 \mathrm{~mL})$ and brine $(15 \mathrm{~mL})$. The organic layer was dried $\left(\mathrm{MgSO}_{4}\right)$ and concentrated to give a crude product that was purified by automated MPLC (gradient from hexane to EtOAc, silica, $15 \mathrm{~min}$ ) to afford DMHCA-Alk (109 mg, 90\%) as a white crystalline solid. ${ }^{1} \mathrm{H}$ NMR $\left(400 \mathrm{MHz}, \mathrm{CDCl}_{3}\right) \delta: 5.37(\mathrm{~d}, J=4.6 \mathrm{~Hz}, 1 \mathrm{H}), 4.71-4.56(\mathrm{~m}, 1 \mathrm{H})$, $3.00(\mathrm{~s}, 3 \mathrm{H}), 2.93(\mathrm{~s}, 3 \mathrm{H}), 2.57-2.44(\mathrm{~m}, 4 \mathrm{H}), 2.41-2.14(\mathrm{~m}, 4 \mathrm{H})$, $2.05-0.88(\mathrm{~m}, 28 \mathrm{H}), 0.68(\mathrm{~s}, 3 \mathrm{H}) .{ }^{13} \mathrm{C} \mathrm{NMR}\left(100 \mathrm{MHz} \mathrm{CDCl}_{3}\right) \delta$ : 173.8, 171.3, 139.7, 122.8, 82.7, 74.5, 69.1, 56.8, 56.0, 50.1, 42.5, 39.8, 38.2 , 37.5, 37.1, 36.7, 35.7, 35.5, 33.8, 32.0, 31.4, 30.5, 28.3, 27.9, 24.4, 21.2, 19.4, 18.7, 14.6, 12.0. IR (ATR): 3321, 2933, 2851, 1733, $1625 \mathrm{~cm}^{-1}$. ESI-MS $(\mathrm{m} / z):$ 482.3632. Calcd for $[\mathrm{M}+\mathrm{H}]^{+}$, $\mathrm{C}_{31} \mathrm{H}_{47} \mathrm{NO}_{3}$ : 482.3634 .

Synthesis of PEG-[G1]-DMHCA. DMHCA-Alk (49 mg, 0.10 mmol) was added to a solution of PEG-[G1]-N $\mathrm{N}_{3}(100 \mathrm{mg}, 17 \mu \mathrm{mol})$ in a mixture of THF $(0.41 \mathrm{~mL})$ and $\mathrm{H}_{2} \mathrm{O}(26 \mu \mathrm{L})$. Then, TBTA $(2.7$ $\mathrm{mg}, 5.10 \mu \mathrm{mol}), \mathrm{CuSO}_{4}(12.8 \mu \mathrm{L}, 2.55 \mu \mathrm{mol}, 0.2 \mathrm{M}, 5 \mathrm{~mol} \%$ per azide), and sodium ascorbate $(64.0 \mu \mathrm{L}, 12.80 \mu \mathrm{mol}, 0.2 \mathrm{M}, 25 \mathrm{~mol} \%$ per azide) were added. After $12 \mathrm{~h}$ of stirring at $60{ }^{\circ} \mathrm{C}$, a second portion of sodium ascorbate $(64.0 \mu \mathrm{L}, 12.80 \mu \mathrm{mol}, 0.2 \mathrm{M}, 25 \mathrm{~mol} \%$ per azide) was added. After additional $24 \mathrm{~h}$ of stirring at $60{ }^{\circ} \mathrm{C}$, the reaction mixture was partitioned between $\mathrm{CH}_{2} \mathrm{Cl}_{2}(15 \mathrm{~mL})$ and $0.1 \mathrm{M}$ EDTA pH $7(15 \mathrm{~mL})$. The organic layer was washed again with $0.1 \mathrm{M}$ EDTA pH $7(2 \times 15 \mathrm{~mL})$ and brine $(15 \mathrm{~mL})$. Then, it was dried $\left(\mathrm{MgSO}_{4}\right)$, evaporated, and purified by precipitation $\left(\mathrm{CH}_{2} \mathrm{Cl}_{2} / \mathrm{Et}_{2} \mathrm{O}\right)$ to afford PEG-[G1]-DMHCA (100 mg, 81\%) as a white solid. ${ }^{1} \mathrm{H}$ $\operatorname{NMR}\left(750 \mathrm{MHz}, \mathrm{CDCl}_{3}\right) \delta: 7.51(\mathrm{~s}, 3 \mathrm{H}), 7.09(\mathrm{~s}, 2 \mathrm{H}), 5.35(\mathrm{~d}, J=$ $5.1 \mathrm{~Hz}, 3 \mathrm{H}), 4.63-4.54(\mathrm{~m}, 3 \mathrm{H}), 4.52-4.42(\mathrm{~m}, 6 \mathrm{H}), 4.26-4.07(\mathrm{~m}$, $8 \mathrm{H}), 3.90-3.50(\mathrm{~m}, \sim 484 \mathrm{H}), 3.40-3.31(\mathrm{~m}, 7 \mathrm{H}), 3.04-2.96(\mathrm{~m}$, $15 \mathrm{H}), 2.93(\mathrm{~s}, 9 \mathrm{H}), 2.72-2.64(\mathrm{~m}, 6 \mathrm{H}), 2.35$ (ddd, $J=15.6,11.0,5.1$ $\mathrm{Hz}, 3 \mathrm{H}), 2.28(\mathrm{~d}, J=8.2 \mathrm{~Hz}, 6 \mathrm{H}), 2.20(\mathrm{ddd}, J=14.8,10.7,5.6 \mathrm{~Hz}$, $3 \mathrm{H}), 2.02-1.92(\mathrm{~m}, 6 \mathrm{H}), 1.91-1.75(\mathrm{~m}, 12 \mathrm{H}), 1.61-1.40(\mathrm{~m}, 20 \mathrm{H})$, $1.36-0.90(\mathrm{~m}, 43 \mathrm{H}), 0.67(\mathrm{~s}, 9 \mathrm{H}) .{ }^{13} \mathrm{C} \mathrm{NMR}\left(100 \mathrm{MHz}, \mathrm{CDCl}_{3}\right) \delta$ : $173.6,172.1,166.9,156.4,152.3,146.2,139.5,129.0,127.9,122.6$, $122.2,107.0,74.1,72.3,71.9,70.8,70.2,69.5,68.8,63.9,59.0,56.6$, $55.9,50.1,49.9,42.3,39.6,38.0,37.3,36.9,36.5,35.6,35.4,34.0$, $31.8,31.2,30.3,28.1,27.7,24.2,21.0,19.3,18.5,11.8$. IR (ATR): $3523,2868,1730,1640,1104 \mathrm{~cm}^{-1}$. MALDI-TOF MS (HABA, linear mode, $m / z)$ : Calcd, $M_{\mathrm{p}} 7251\left([\mathrm{M}+\mathrm{H}]^{+}\right), M_{\mathrm{n}} 7278$; Found, $M_{\mathrm{p}} 7258$ $\left([\mathrm{M}+\mathrm{H}]^{+}\right), M_{\mathrm{n}} 7243, M_{\mathrm{w}} 7272$.

Preparation of DMHCA Micelles. PEG-[G1]-DMHCA was dissolved in a mixture of acetone $/ \mathrm{H}_{2} \mathrm{O}(1: 1,0.5 \mathrm{mg} / \mathrm{mL})$ and stirred at room temperature for $48 \mathrm{~h}$ until acetone was completely evaporated. The resulting micelles $(1 \mathrm{mg} / \mathrm{mL})$ were freeze-dried. Biotin-PEG-[G1]-DMHCA micelles with a $10 \%$ biotin loading were prepared following the same procedure as above from a mixture of PEG-[G1]-DMHCA and Biotin-PEG-[G1]-DMHCA in a molar ratio 9:1. DLS histograms and correlation functions of the micelles as prepared and after resuspension in $10 \mathrm{mM} \mathrm{PB}, \mathrm{pH} 7.4,150 \mathrm{mM} \mathrm{NaCl}$ $(1 \mathrm{mg} / \mathrm{mL})$ are shown in Figure S2-S4.

${ }^{1} \mathrm{H}$ NMR analysis of the micelles revealed at a glance that there is a core-corona structure (Figure S5). Only resonances for the flexible PEG chains at the hydrophilic corona are visible, whereas nuclei from DMHCA and the dendritic block are absent from the spectrum as a result of their restricted mobility at the compact core. Interestingly, no ester hydrolysis is observed during the preparation/storage of the micelles as revealed by the ${ }^{1} \mathrm{H}$ NMR of a lyophilized sample of micelles after being redissolved in $\mathrm{CDCl}_{3}$ (Figure S6).

Primary Neuronal/Glial Cultures. Primary cortical cells (neurons cocultured with glia) were obtained from embryonic rats using a standard procedure. Briefly, 8-10 embryos E15-16 were extracted from the uterus of pregnant Wistar rats and cerebral cortices were isolated in HBSS buffer (Thermo Scientific). The tissue was incubated with $2 \mathrm{~mL}$ of $0.25 \%$ trypsin-EDTA (Thermo Scientific) for $15 \mathrm{~min}$ at $37^{\circ} \mathrm{C}$ and then washed twice with DMEM/F12-10\% FBS. The medium was replaced by Neurobasal (Thermo Scientific) and cortices were homogenized by pipetting up and down. After that, cells were incubated for $10 \mathrm{~min}$ at room temperature and then centrifuged at $200 \times \mathrm{g}$ for $5 \mathrm{~min}$. The medium was discarded and replaced with 2 $\mathrm{mL}$ of neuronal medium (Neurobasal, $2 \mathrm{mM}$ L-glutamine, 2\% B27 (Thermo Scientific), $100 \mathrm{U} / \mathrm{mL}$ penicillin, $100 \mu \mathrm{g} / \mathrm{mL}$ streptomycin). Cells were resuspended, and viability was assessed with Trypan blue dye. Then, cells were plated in previously poly-L-lysine coated $12 \mathrm{~mm}$ diameter coverslips for immunofluorescence experiments (150000 cells per coverslip) or 6-multiwell plates for Western blot experiments (800000 cells per well) and maintained in a $37{ }^{\circ} \mathrm{C}$ humidified incubator with $5 \% \mathrm{CO}_{2}$ until DIV (days in vitro) 14.

In Vitro Biological Effects. The primary cell culture was plated at 800000 cells per well in 6-well plates. Immediately, PEG-[G1]- $\mathrm{CO}_{2} \mathrm{H}$ (control), free DMHCA, or PEG-[G1]-DMHCA micelles were added to the conditioned medium of DIV14 cells to a final concentration of $10 \mu \mathrm{M}$ DMHCA. Cultures were then incubated in a $37^{\circ} \mathrm{C}$ humidified incubator with $5 \% \mathrm{CO}_{2}$ for $24 \mathrm{~h}$. After incubation, the conditioned medium was aspirated and cells (neurons and glia) were washed in cold PBS and lysed in RIPA buffer containing protease inhibitors (SigmaFast protease inhibitor, St. Louis, MO).

Cell Uptake Experiment and Fluorescence Imaging In Vitro. Biotin-PEG-[G1]-DMHCA micelles were added to the conditioned medium of DIV14 cells to a final concentration of $10 \mu \mathrm{M}$ of DMHCA, 
and cultures were then incubated in a $37{ }^{\circ} \mathrm{C}$ humidified incubator with $5 \% \mathrm{CO}_{2}$ for $2 \mathrm{~h}$. Then, the conditioned medium was aspirated, and cultures were washed with cold PBS and fixed in 4\% PFA. Cells were incubated with primary antibodies anti- $\beta$ III-tubulin $(1: 1000$, mouse, Promega) or antiglial fibrillary acidic protein (GFAP 1:1000, rabbit, Dako) overnight at $4{ }^{\circ} \mathrm{C}$, followed by incubation with secondary antibodies labeled with Alexa Fluor 488 (green) or streptavidin-Alexa Fluor 594 (red). Coverslips were mounted with Mounting Medium with DAPI (blue) and images were obtained with a confocal Zeiss LSM 510 Meta microscope with a $40 \times$ oil-immersion lens and analyzed with LSM5 image browser software.

Confocal Fluorescence Imaging. Mice received a single intranasal dose of Biotin-PEG-[G1]-DMHCA micelles $(0.6 \mathrm{mg}$ in $10 \mu \mathrm{L} \mathrm{PBS}$ ), and $24 \mathrm{~h}$ later their brains were perfused-fixed. Then, 30 $\mu \mathrm{m}$ thick sections containing the hippocampus and cerebral cortex regions were prepared, and double immunostaining was performed to identify astrocytes and Biotin-PEG-[G1]-DMHCA. DAPI was added to stain nuclei (blue). Astrocytes were identified with rabbit antiglial fibrillary acidic protein (GFAP 1:1000, rabbit, Dako) followed by incubation with secondary antibodies labeled with Alexa Fluor 594 (red). Biotin-PEG-[G1]-DMHCA was identified using streptavidinAlexa Fluor 488 (green). In all cases, sections were preincubated, blocked with the corresponding normal serum secondary antibody and coverslips were mounted with Gelvatol. The colocalization of Biotin-PEG-[G1]-DMHCA and astrocytes marker images were obtained with a confocal Zeiss LSM 510 Meta microscope with a $40 \times$ oil-immersion lens and analyzed with LSM5 image browser software.

Animals, Intranasal Delivery Dose-Response, and Treatment Experiments. Three-month-old mice $(n=4-5 /$ condition $)$ were weighed and assigned to treatment groups. Mice received daily intranasal delivery of control (PEG-[G1]- $\mathrm{CO}_{2} \mathrm{H}$ or saline) or PEG[G1]-DMHCA micelles in PBS. The intranasal delivery was performed according to the protocol described by Hanson et al. ${ }^{42}$ First, mice were subjected to simulated delivery for 1 week before treatments to reduce the stress due to the procedure.

For intranasal delivery, mice were hand-restrained, placed in a supine position, and given two $5 \mu \mathrm{L}$ drops of PEG-[G1]-DMHCA micelles, or a control solution, into both nostrils consecutively. Mice were given an extra $5 \mu \mathrm{L}$ treatment drop if the subject forcibly ejected or sneezed out the solution. Mice were held supine for 5-10 s after delivery to ensure that all fluid was inhaled. These volumes have shown to deliver drugs mostly to the brain without passage to the pulmonary regions. For dose-response experiments, mice received a range of 0.01 to $0.5 \mathrm{mg}$ DMHCA per animal contained into micelles (equivalent to $0.3-15 \mathrm{mg} \mathrm{DMHCA} / \mathrm{kg}$ body weight/day).

For treatment experiments, McGill-Thy1-APP transgenic ( $\mathrm{Tg}$ ) mice were three months old when they started the treatment and were sacrificed 21 days after. Young, preplaque three month old $\mathrm{Tg}$ mice received $15 \mathrm{mg} / \mathrm{kg}$ body weight/day of PEG-[G1]-CO $\mathrm{CO}_{2} \mathrm{H}(\mathrm{Tg}$ control) or $15 \mathrm{mg} / \mathrm{kg}$ body weight/day of PEG-[G1]-DMHCA micelles by intranasal administration for a 3 week period (non $\mathrm{Tg}$ control, $n=5$ received intranasal administration of PBS; Tg/PEG[G1]- $\mathrm{CO}_{2} \mathrm{H}, n=5$; Tg/PEG-[G1]-DMHCA micelles, $n=5$ ). The animals were housed in groups of up to four in individually ventilated cages under standard conditions $\left(22{ }^{\circ} \mathrm{C}, 12 \mathrm{~h}\right.$ light-dark cycle) receiving food and water ad libitum. All procedures were approved by the Animal Care Committee of the Catholic University of Cuyo, Argentine and followed the guidelines of the Argentinean Council on Animal Care.

Perfusion and Tissue Preparation Technique. Experimental mice were deeply anesthetized with equithesin (pentobarbital-based, $2.5 \mathrm{~mL} / \mathrm{kg}$, i.p.) and perfused through the heart with ice-cold saline solution ( $\mathrm{pH} 7.4$ ) for $1 \mathrm{~min}$. The brains were then quickly removed and divided into right and left hemispheres on ice. The cortex, hippocampus, and olfactory bulb were dissected from the left hemisphere, snap-frozen in dry ice, and stored at $-80{ }^{\circ} \mathrm{C}$ for biochemical analysis. The same treatment was applied to the liver. The right hemisphere was fixed in $4 \%$ paraformaldehyde (PFA) in 0.1 $\mathrm{M}$ phosphate buffer (PBS, pH 7.4) for $24 \mathrm{~h}$ at $4{ }^{\circ} \mathrm{C}$. The tissue was then cut into $30 \mu \mathrm{m}$ thick sections with a freezing sledge microtome (SM 2000R, Leica) at $-20{ }^{\circ} \mathrm{C}$ and free-floating sections were collected in PBS and processed for immunofluorescence.

Plasma Lipid Parameters. Blood was withdrawn intracardially and EDTA-plasma was prepared within $20 \mathrm{~min}$. Plasma TG (Wiener lab, Argentine) and total cholesterol (Wiener lab, Argentine) concentrations were measured enzymatically.

Novel Object Recognition Test. The NOR (Novel Object Recognition) was performed according to established protocols. ${ }^{43}$ Briefly, three month old mice, $\mathrm{Tg}$ and non $\mathrm{Tg}$ subjected to treatment, were habituated first to an empty open field box of $50 \mathrm{~cm} \times 50 \mathrm{~cm} \times$ $30 \mathrm{~cm}$ (for $10 \mathrm{~min}$ ). After $24 \mathrm{~h}$ of the habituation session, mice were exposed to two identical nontoxic "familiar" objects (culture bottles filled with sand, T25). Between each test, the open field was cleaned with $70 \%$ ethanol to eliminate olfactory signals. After a retention interval of $4 \mathrm{~h}$, animals were again exposed to the field where two objects were located, one familiar and one novel (insert cube, red). The definition of exploring that was used consists of detecting that the mouse was sniffing, climbing or touching the object or was at a distance of at least $3 \mathrm{~cm}$ from the object, while facing it or facing it. Each session lasted $10 \mathrm{~min}$, and during this time mice were allowed to interact freely with the objects and the amount of exploration time of each object was recorded with the HVS Image software. The objects were randomized and counterbalanced through the animals. Animals that spent less than $7 \mathrm{~s}$ exploring objects during the $10 \mathrm{~min}$ training session were excluded from the analysis.

\section{ASSOCIATED CONTENT}

\section{SI Supporting Information}

The Supporting Information is available free of charge at https://pubs.acs.org/doi/10.1021/acsnano.0c09159.

Materials, instrumentation, synthesis of DMHCA, Table S1, characterization of DMHCA-Alk and PEG-[G1]DMHCA, synthesis and characterization of Biotin-PEG[G1]-DMHCA, DLS and NMR characterization of PEG-[G1]-DMHCA micelles, Western blotting, immunohistochemistry and data analysis (PDF)

\section{AUTHOR INFORMATION}

\section{Corresponding Authors}

Martin A. Bruno - Instituto de Ciencias Biomédicas, Facultad de Ciencias Médicas, Universidad Católica de Cuyo, 5400 San Juan, Argentina; National Council of Scientific and Technical Research (CONICET), C1425FQB Ciudad Autónoma de Buenos Aires, Argentina; 이이.org/00000001-6005-5108; Email: martinbruno_investigacion@ uccuyo.edu.ar

Eduardo Fernandez-Megia - Centro Singular de Investigación en Química Biolóxica e Materiais Moleculares (CIQUS) and Departamento de Química Orgánica, Universidade de Santiago de Compostela, 15782 Santiago de Compostela, Spain; 이이.org/0000-0002-0405-4933; Email: ef.megia@usc.es

\section{Authors}

María Eugenia Navas Guimaraes - Instituto de Ciencias Biomédicas, Facultad de Ciencias Médicas, Universidad Católica de Cuyo, 5400 San Juan, Argentina; National Council of Scientific and Technical Research (CONICET), C1425FQB Ciudad Autónoma de Buenos Aires, Argentina

Roi Lopez-Blanco - Centro Singular de Investigación en Química Biolóxica e Materiais Moleculares (CIQUS) and Departamento de Química Orgánica, Universidade de Santiago de Compostela, 15782 Santiago de Compostela, Spain 
Juan Correa - Centro Singular de Investigación en Química Biolóxica e Materiais Moleculares (CIQUS) and Departamento de Química Orgánica, Universidade de Santiago de Compostela, 15782 Santiago de Compostela, Spain

Marcos Fernandez-Villamarin - Centro Singular de Investigación en Química Biolóxica e Materiais Moleculares (CIQUS) and Departamento de Química Orgánica, Universidade de Santiago de Compostela, 15782 Santiago de Compostela, Spain

María Beatriz Bistué - Instituto de Ciencias Biomédicas, Facultad de Ciencias Médicas, Universidad Católica de Cuyo, 5400 San Juan, Argentina

Pamela Martino-Adami - Laboratory of Brain Aging and Neurodegeneration, Fundación Instituto Leloir, C1405BWE Ciudad Autónoma de Buenos Aires, Argentina

Laura Morelli - Laboratory of Brain Aging and Neurodegeneration, Fundación Instituto Leloir, C1405BWE Ciudad Autónoma de Buenos Aires, Argentina

Vijay Kumar - School of Pharmacy, Department of Pharmaceutical Sciences, University of Colorado, Aurora, Colorado 80045, United States

Michael F. Wempe - School of Pharmacy, Department of Pharmaceutical Sciences, University of Colorado, Aurora, Colorado 80045, United States

A. C. Cuello - Department of Pharmacology and Therapeutics, McGill University, Montreal, Quebec H3G 1Y6, Canada

Complete contact information is available at:

https://pubs.acs.org/10.1021/acsnano.0c09159

\section{Author Contributions}

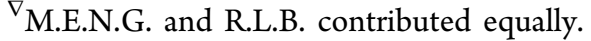

\section{Author Contributions}

M.E.N.G. conducted in vitro and in vivo experiments, contributed with data analysis and writing the manuscript; R.L.B. conducted chemical experiments, contributed data analysis and writing the manuscript. Both M.E.N.G. and R.L.B. share cofirst authorship. J.C. and M.F.V. designed chemical studies; M.B.B., L.M., and P.A. designed in vitro studies; M.F.W. and V.K. designed and synthesized DMHCA, revised the manuscript; A.C.C. collaborated with transgenic mouse model; E.F.M. and M.A.B. designed and supervised experiments, wrote the manuscript, and are both corresponding authors. All authors contributed to data interpretation and reviewed, edited, and approved the manuscript before submission.

\section{Notes}

The authors declare no competing financial interest.

\section{ACKNOWLEDGMENTS}

This work was supported by PICT-2013-2840 (PI: M.A. B.), the Spanish Ministry of Science and Innovation (RTI2018102212-B-I00), the Xunta de Galicia (ED431C 2018/30, and Centro singular de investigación de Galicia accreditation 2019-2022, ED431G2019/03), Axencia Galega de Innovación (IN845D 2020/09), and the European Union (European Regional Development Fund-ERDF).

\section{REFERENCES}

(1) Schmechel, D. E.; Saunders, A. M.; Strittmatter, W. J.; Crain, B. J.; Hulette, C. M.; Joo, S. H.; Pericak-Vance, M. A.; Goldgaber, D.;
Roses, A. D. Increased Amyloid Beta-Peptide Deposition in Cerebral Cortex as a Consequence of Apolipoprotein E Genotype in LateOnset Alzheimer Disease. Proc. Natl. Acad. Sci. U. S. A. 1993, 90, 9649-9653.

(2) Hardy, J.; Selkoe, D. J. The Amyloid Hypothesis of Alzheimer's Disease: Progress and Problems on the Road to Therapeutics. Science 2002, 297, 353-356.

(3) Selkoe, D. J.; Hardy, J. The Amyloid Hypothesis of Alzheimer's Disease at 25 Years. EMBO Mol. Med. 2016, 8, 595-608.

(4) Nelson, P. T.; Alafuzoff, I.; Bigio, E. H.; Bouras, C.; Braak, H.; Cairns, N. J.; Castellani, R. J.; Crain, B. J.; Davies, P.; Del Tredici, K.; Duyckaerts, C.; Frosch, M. P.; Haroutunian, V.; Hof, P. R.; Hulette, C. M.; Hyman, B. T.; Iwatsubo, T.; Jellinger, K. A.; Jicha, G. A.; Kovari, E.; et al. Correlation of Alzheimer Disease Neuropathologic Changes with Cognitive Status: A Review of the Literature. J. Neuropathol. Exp. Neurol. 2012, 71, 362-381.

(5) DeTure, M. A.; Dickson, D. W. The Neuropathological Diagnosis of Alzheimer's Disease. Mol. Neurodegener. 2019, 14, 1432.

(6) Haass, C.; Selkoe, D. J. Soluble Protein Oligomers in Neurodegeneration: Lessons from the Alzheimer's Amyloid BetaPeptide. Nat. Rev. Mol. Cell Biol. 2007, 8, 101-112.

(7) Ferreira, S. T.; Lourenco, M. V.; Oliveira, M. M.; De Felice, F. G. Soluble Amyloid-Beta Oligomers as Synaptotoxins Leading to Cognitive Impairment in Alzheimer's Disease. Front. Cell. Neurosci. 2015, 9, 191-207.

(8) Guenette, S. Y. Astrocytes: A Cellular Player in Abeta Clearance and Degradation. Trends Mol. Med. 2003, 9, 279-280.

(9) Miners, J. S.; Baig, S.; Palmer, J.; Palmer, L. E.; Kehoe, P. G.; Love, S. Abeta-Degrading Enzymes in Alzheimer's Disease. Brain Pathol. 2008, 18, 240-252.

(10) Raber, J.; Huang, Y.; Ashford, J. W. ApoE Genotype Accounts for the Vast Majority of $\mathrm{AD}$ Risk and $\mathrm{AD}$ Pathology. Neurobiol. Aging 2004, 25, 641-650.

(11) Schmidt, V.; Carlo, A. S.; Willnow, T. E. Apolipoprotein E Receptor Pathways in Alzheimer Disease. WIREs Syst. Biol. Med. 2014, 6, 255-270.

(12) Yang, D. S.; Small, D. H.; Seydel, U.; Smith, J. D.; Hallmayer, J.; Gandy, S. E.; Martins, R. N. Apolipoprotein E Promotes the Binding and Uptake of Beta-Amyloid into Chinese Hamster Ovary Cells in an Isoform-Specific Manner. Neuroscience 1999, 90, 1217-1226.

(13) Koldamova, R. P.; Lefterov, I. M.; Staufenbiel, M.; Wolfe, D.; Huang, S.; Glorioso, J. C.; Walter, M.; Roth, M. G.; Lazo, J. S. The Liver X Receptor Ligand T0901317 Decreases Amyloid Beta Production in Vitro and in a Mouse Model of Alzheimer's Disease. J. Biol. Chem. 2005, 280, 4079-4088.

(14) Wahrle, S. E.; Jiang, H.; Parsadanian, M.; Kim, J.; Li, A.; Knoten, A.; Jain, S.; Hirsch-Reinshagen, V.; Wellington, C. L.; Bales, K. R.; Paul, S. M.; Holtzman, D. M. Overexpression of ABCA1 Reduces Amyloid Deposition in the PDAPP Mouse Model of Alzheimer Disease. J. Clin. Invest. 2008, 118, 671-682.

(15) Hirsch-Reinshagen, V.; Maia, L. F.; Burgess, B. L.; Blain, J. F.; Naus, K. E.; McIsaac, S. A.; Parkinson, P. F.; Chan, J. Y.; Tansley, G. H.; Hayden, M. R.; Poirier, J.; Van Nostrand, W.; Wellington, C. L. The Absence of ABCA1 Decreases Soluble ApoE Levels but Does Not Diminish Amyloid Deposition in Two Murine Models of Alzheimer Disease. J. Biol. Chem. 2005, 280, 43243-43256.

(16) Wahrle, S. E.; Jiang, H.; Parsadanian, M.; Hartman, R. E.; Bales, K. R.; Paul, S. M.; Holtzman, D. M. Deletion of ABCA1 Increases Abeta Deposition in the PDAPP Transgenic Mouse Model of Alzheimer Disease. J. Biol. Chem. 2005, 280, 43236-43242.

(17) Zelcer, N.; Tontonoz, P. Liver X Receptors as Integrators of Metabolic and Inflammatory Signaling. J. Clin. Invest. 2006, 116, 607614

(18) Fowler, A. J.; Sheu, M. Y.; Schmuth, M.; Kao, J.; Fluhr, J. W.; Rhein, L.; Collins, J. L.; Willson, T. M.; Mangelsdorf, D. J.; Elias, P. M.; Feingold, K. R. Liver X Receptor Activators Display AntiInflammatory Activity in Irritant and Allergic Contact Dermatitis Models: Liver-X-Receptor-Specific Inhibition of Inflammation and 
Primary Cytokine Production. J. Invest. Dermatol. 2003, 120, 246255.

(19) Donkin, J. J.; Stukas, S.; Hirsch-Reinshagen, V.; Namjoshi, D.; Wilkinson, A.; May, S.; Chan, J.; Fan, J.; Collins, J.; Wellington, C. L. ATP-Binding Cassette Transporter A1Mediates the Beneficial Effects of the Liver X Receptor Agonist GW3965 on Object Recognition Memory and Amyloid Burden in Amyloid Precursor Protein/ Presenilin 1 Mice. J. Biol. Chem. 2010, 285, 34144-34154.

(20) Morales, J. R.; Ballesteros, I.; Deniz, J. M.; Hurtado, O.; Vivancos, J.; Nombela, F.; Lizasoain, I.; Castrillo, A.; Moro, M. A. Activation of Liver X Receptors Promotes Neuroprotection and Reduces Brain Inflammation in Experimental Stroke. Circulation 2008, 118, 1450-1459.

(21) Suon, S.; Zhao, J.; Villarreal, S. A.; Anumula, N.; Liu, M.; Carangia, L. M.; Renger, J. J.; Zerbinatti, C. V. Systemic Treatment with Liver X Receptor Agonists Raises Apolipoprotein E, Cholesterol, and Amyloid-Beta Peptides in the Cerebral Spinal Fluid of Rats. Mol. Neurodegener. 2010, 5, 44-57.

(22) Kratzer, A.; Buchebner, M.; Pfeifer, T.; Becker, T. M.; Uray, G.; Miyazaki, M.; Miyazaki-Anzai, S.; Ebner, B.; Chandak, P. G.; Kadam, R. S.; Calayir, E.; Rathke, N.; Ahammer, H.; Radovic, B.; Trauner, M.; Hoefler, G.; Kompella, U. B.; Fauler, G.; Levi, M.; Levak-Frank, S.; et al. Synthetic LXR Agonist Attenuates Plaque Formation in ApoE-/ - Mice without Inducing Liver Steatosis and Hypertriglyceridemia. J. Lipid Res. 2009, 50, 312-326.

(23) Quinet, E. M.; Savio, D. A.; Halpern, A. R.; Chen, L.; Miller, C. P.; Nambi, P. Gene-Selective Modulation by a Synthetic Oxysterol Ligand of the Liver X Receptor. J. Lipid Res. 2004, 45, 1929-1942.

(24) Pfeifer, T.; Buchebner, M.; Chandak, P. G.; Patankar, J.; Kratzer, A.; Obrowsky, S.; Rechberger, G. N.; Kadam, R. S.; Kompella, U. B.; Kostner, G. M.; Kratky, D.; Levak-Frank, S. Synthetic LXR Agonist Suppresses Endogenous Cholesterol Biosynthesis and Efficiently Lowers Plasma Cholesterol. Curr. Pharm. Biotechnol. 2011, 12, 285-292.

(25) Sousa-Herves, A.; Riguera, R.; Fernandez-Megia, E. PEGDendritic Block Copolymers for Biomedical Applications. New J. Chem. 2012, 36, 205-210.

(26) Knop, K.; Hoogenboom, R.; Fischer, D.; Schubert, U. S. Poly (ethylene Glycol) in Drug Delivery: Pros and Cons as Well as Potential Alternatives. Angew. Chem., Int. Ed. 2010, 49, 6288-6308.

(27) Amaral, S. P.; Tawara, M. H.; Fernandez-Villamarin, M.; Borrajo, E.; Martinez-Costas, J.; Vidal, A.; Riguera, R.; FernandezMegia, E. Tuning the Size of Nanoassembles: A Hierarchical Transfer of Information from Dendrimers to Polyion Complexes. Angew. Chem., Int. Ed. 2018, 57, 5273-5277.

(28) Vukojicic, P.; Behar, G.; Tawara, M. H.; Fernandez-Villamarin, M.; Pecorari, F.; Fernandez-Megia, E.; Mouratou, B. Multivalent Affidendrons with High Affinity and Specificity toward Staphylococcus aureus as Versatile Tools for Modulating Multicellular Behaviors. ACS Appl. Mater. Interfaces 2019, 11, 21391-21398.

(29) Lopez-Blanco, R.; Fernandez-Villamarin, M.; Jatunov, S.; Novoa-Carballal, R.; Fernandez-Megia, E. Polysaccharides Meet Dendrimers to Fine-Tune the Stability and Release Properties of Polyion Complex Micelles. Polym. Chem. 2019, 10, 4709-4717.

(30) Leiro, V.; Garcia, J. P.; Tomas, H.; Pego, A. P. The Present and the Future of Degradable Dendrimers and Derivatives in Theranostics. Bioconjugate Chem. 2015, 26, 1182-1197.

(31) Redasani, V. K.; Bari, S. B. Prodrug Design: Perspectives, Approaches and Applications in Medicinal Chemistry; Academic Press: Boston, 2015.

(32) Jornada, D. H.; dos Santos Fernandes, G. F.; Chiba, D. E.; de Melo, T. R.; dos Santos, J. L.; Chung, M. C. The Prodrug Approach: A Successful Tool for Improving Drug Solubility. Molecules 2016, 21, $42-72$.

(33) Sousa-Herves, A.; Novoa-Carballal, R.; Riguera, R.; FernandezMegia, E. GATG Dendrimers and PEGylated Block Copolymers: From Synthesis to Bioapplications. AAPS J. 2014, 16, 948-961.

(34) Rostovtsev, V. V.; Green, L. G.; Fokin, V. V.; Sharpless, K. B. A Stepwise Huisgen Cycloaddition Process: Copper(I)-Catalyzed
Regioselective "Ligation" of Azides and Terminal Alkynes. Angew. Chem., Int. Ed. 2002, 41, 2596-2599.

(35) Fernandez-Villamarin, M.; Sousa-Herves, A.; Correa, J.; Munoz, E. M.; Taboada, P.; Riguera, R.; Fernandez-Megia, E. The Effect of PEGylation on Multivalent Binding: A Surface Plasmon Resonance and Isothermal Titration Calorimetry Study with Structurally Diverse PEG-Dendritic GATG Copolymers. ChemNanoMat 2016, 2, 437446.

(36) Fernandez-Villamarin, M.; Sousa-Herves, A.; Porto, S.; Guldris, N.; Martínez-Costas, J.; Riguera, R.; Fernandez-Megia, E. A Dendrimer-Hydrophobic Interaction Synergy Improves the Stability of Polyion Complex Micelles. Polym. Chem. 2017, 8, 2528-2537.

(37) Mignani, S.; Shi, X.; Karpus, A.; Majoral, J.-P. Non-Invasive Intranasal Administration Route Directly to the Brain Using Dendrimer Nanoplatforms: An Opportunity to Develop New CNS Drugs. Eur. J. Med. Chem. 2021, 209, 112905.

(38) Alexander, A.; Agrawal, M.; Chougule, M. B.; Saraf, S.; Saraf, S. Nose-to-Brain Drug Delivery: An Alternative Approach for Effective Brain Drug Targeting. Nanopharmaceuticals; Shegokar, R., Ed.; Elsevier: Amsterdam, 2020; pp 175-200.

(39) Wang, Z.; Xiong, G.; Tsang, W. C.; Schätzlein, A. G.; Uchegbu, I. F. Nose-to-Brain Delivery. J. Pharmacol. Exp. Ther. 2019, 370, 593601.

(40) El-Darzi, N.; Astafev, A.; Mast, N.; Saadane, A.; Lam, M.; Pikuleva, I. A. N,N-Dimethyl-3beta-Hydroxycholenamide Reduces Retinal Cholesterol via Partial Inhibition of Retinal Cholesterol Biosynthesis Rather than Its Liver X Receptor Transcriptional Activity. Front. Pharmacol. 2018, 9, 827-838.

(41) Ferretti, M. T.; Partridge, V.; Leon, W. C.; Canneva, F.; Allard, S.; Arvanitis, D. N.; Vercauteren, F.; Houle, D.; Ducatenzeiler, A.; Klein, W. L.; Glabe, C. G.; Szyf, M.; Cuello, A. C. Transgenic Mice as a Model of Pre-Clinical Alzheimer's Disease. Curr. Alzheimer Res. 2011, 8, 4-23.

(42) Hanson, L. R.; Fine, J. M.; Svitak, A. L.; Faltesek, K. A. Intranasal Administration of CNS Therapeutics to Awake Mice. J. Vis. Exp. 2013, 74, 4440-4446.

(43) Lueptow, L. M. Novel Object Recognition Test for the Investigation of Learning and Memory in Mice. J. Vis. Exp. 2017, 126, 55718-55726. 